УДК 346.22:346.52

DOI https://doi.org/10.32849/2663-5313/2020.3.14

\title{
Юрій Ніколаєнко,
}

студент магістратури

юридичного факультету

Київського начіонального університету імені Тараса Шевченка

\section{ТЕОРЕТИЧНІ ТА ПРАКТИЧНІ ПИТАННЯ ВИЗНАЧЕННЯ КОЛА ЗАМОВНИКІВ У СФЕРІ ПУБЛІЧНИХ ЗАКУПІВЕЛЬ}

Стаття присвячена висвітленню новел начіонального законодавства про публічні закупівлі в частині визначення кола замовників, які зобов'язані здійснювати закупівлі шляхом застосування встановлених законом процедур. Визначається, що оновленим законодавством про публічні закупівлі модернізовано перелік замовників, що спричиняє виникнення інтересу у представників наукової спільноти у разі виявлення недоліків нормативно-правового регулювання.

У статті обгрунтовується, що законодавець безпідставно оминув низку державних органів, які відповідно до чинного законодавства не входять до жодної із гілок влади, не є правоохоронними, при иьому, однак, реалізують владні повноваження виконання регулюючих функиій держави в окремих сферах господарської діяльності. Також доводиться, що в законі міститься застарілий поділ юридичних осіб на підприємства, установи, організаиї̈, який за своєю суттю не несе жодної теоретичної або практичної иінності під час вирішення питання, чи є окрема юридична особа замовником. Наголошується на наявності проблеми під час визначення характеристик здійснення господарської діяльності на промисловій чи комериійній основах, що підтверджується здійсненням проиедур закупівель державними комериійними підприємствами, чия господарська діяльність згідно з положеннями чинного законодавства є комериійною, тобто орієнтованою на прибуток. Поряд із цим обгрунтовано, що у законі без достатніх для того підстав проведено поділ між категоріями «юридичні особи» та «суб'єкти господарювання» як між такими, зміст яких не перетинається. Окрім иього, у статті робиться висновок про недопустимість зазначення у законі про ознаку належності органам державної влади чи органам місцевого самоврядування часток у статутному капіталі юридичної особи. Додатково вказується на наявність у законі одного випадку, коли належність юридичної особи, що здійснює діяльність в окремих сферах господарювання, до переліку замовників встановлюється незалежно від наявності зв'язку між такою юридичною особою та органами державної влади, органами місиевого самоврядування та органами влади Автономної Республіки Крим.

Ключові слова: замовники, публічні закупівлі, окремі сфери господарювання, органи державної влади, органи місцевого самоврядування, комерційна діяльність.

Постановка проблеми. Національне законодавство про публічні закупівлі перебуває у стані реформування. На користь цього свідчить прийняття Верховною Радою України Закону України «Про внесення змін до Закону України «Про публічні закупівлі» та деяких інших законодавчих актів України щодо вдосконалення публічних закупівель» № 114-IX від 19.09.2019, яким Закон України «Про публічні закупівлі» (далі - Закон про публічні закупівлі) викладено у новій редакції. Постійне вдосконалення законодавцем положень закону, якими регулюються правовідносини у сфері закупівель товарів, робіт чи послуг за публічні кошти або кошти суб'єктів господарювання державного сектору економіки, зумовлено обгрунтованим прагненням встановити саме такі норми, правильне застосування яких забезпечить належну реалізацію суспільних інтересів у частині ефективного використання зазначених грошових коштів. Разом із тим внесення численних змін до законодавства очікувано спричиняє потребу в проведенні наукового аналізу введених новел, в тому числі й з критичної точку зору, оскільки тільки за наявності постійного співробітництва між науковою спільнотою та суб'єктами нормотворчості можливе досягнення високого стандарту якості нормативно-правових актів, як наслідок, ефективна реалізація аналізованих правовідносин.

Аналіз останніх досліджень та публікацій. Окремим аспектам публічних закупівель приділено увагу з боку таких фахівців, як: Я. Горбатюк, О. Довбенко, О. Єжель, А. Олефір, Я. Петруненко, О. Шатковський, О. Юдицький, С. Яременко та інші. 
Водночас слід визнати, що проблемним питанням визначення кола замовників у сфері публічних закупівель приділено не досить уваги, адже зазвичай вирішення цього питання обмежується вказівкою на особливість кола учасників правовідносин у сфері публічних закупівель, а наявна в літературі класифікація є застарілою з огляду на оновлення законодавства.

Метою статті є визначення юридично значущих ознак юридичних осіб, наявність яких дає підстави для віднесення їх до кола замовників у розумінні оновленого Закону про публічні закупівлі (тут і далі мається на увазі редакція Закону про публічні закупівлі, що набере чинності 19.04.2020 - Ю. Н.), проведення критичного аналізу недосконалих формулювань, що їх вжито у законі, а також встановлення на підставі проведеного аналізу перспектив майбутніх наукових досліджень ॥ цього питання.

Виклад основного матеріалу. У науковій юридичній літературі міститься поділ замовників, які мають 3 метою закупівлі товарів, робіт чи послуг проводити передбачені законом процедури. До них відносять «традиційних замовників-бюджетників», до складу яких входять органи державної влади, органи місцевого самоврядування, органи соціального страхування та бюджетні установи, «підприємства» - державні та комунальні підприємства, які забезпечують потреби держави та територіальної громади, якщо така діяльність не здійснюється на комерційній чи промисловій основі за наявності певних ознак, та «монополістів» - переважно державної або комунальної власності, які займають переважно монопольне становище у чітко перерахованих у законі суспільно важливих сферах діяльності [1, с. 13-14].

Утім, у ч. 1 ст. 2 Закону про публічні закупівлі міститься модернізований перелік осіб, які мають проводити процедури закупівлі, а саме: встановлено чотири категорії замовників, кожна 3 яких потребує детального дослідження. У розумінні п. 1 ч. 1 ст. 2 Закону до органів державної влади належать орган законодавчої влади, яким відповідно до ст. 75 Конституції України є Верховна Рада України, органи виконавчої влади, якими відповідно до ч. 1 ст. 113, ч. 1 ст. 118 Основного Закону України та ч. 1 ст. 1 Закону України «Про центральні органи виконавчої влади» є Кабінет Міністрів України, місцеві державні адміністрації, міністерства та інші центральні органи виконавчої влади, а також органи судової влади. До правоохоронних органів держави, які не входять до жодної, передбаченої ч. 1 ст. 6 Конституції України, гілки влади належать, зокрема, органи прокуратури України (Офіс Генерального прокурора, обласні та окружні прокуратури), Національне антикорупційне бюро України (державний правоохоронний орган), Служба безпеки України (державний орган спеціального призначення 3 правоохоронними функціями) тощо. Разом із тим законодавець безпідставно не врахував, що відповідно до положень чинного законодавства України $€$ державні органи, які згідно з визначеним законом статусом не належать до жодної з гілок влади та одночасно за своїм функціональним призначенням та компетенцією не $є$ правоохоронними. Так, наприклад, відповідно до ч. 1 ст. 6 Закону України «Про державне регулювання ринку цінних паперів в Україні» Національна комісія з цінних паперів та фондового ринку є державним колегіальним органом, підпорядкованим Президенту України, підзвітним Верховній Раді України. Ідентичний статус відповідно до законодавства надано Національній комісії, що здійснює державне регулювання у сфері зв'язку та інформатизації, і Національній комісії, що здійснює державне регулювання у сфері ринків фінансових послуг. Не заперечуючи невідповідність Конституції України таких положень наведених законів, водночас ураховуючи, що відповідно до ч. 2 ст. 152 Конституції України закони, інші акти або їх окремі положення, що визнані неконституційними, втрачають чинність 3 дня ухвалення Конституційним Судом України рішення про їх неконституційність, якщо інше не встановлено самим рішенням, але не раніше дня його ухвалення. Вважаємо положення п. 1 ч. 1 ст. 2 Закону про публічні закупівлі недосконалим, таким, що не охоплює окремі державні органи, та таким, що потребує вдосконалення шляхом включення до цього переліку терміна «інші державні органи України» замість терміна «правоохоронні органи держави» [2].

Коло осіб, що входять до другої категоpiї замовників згідно з п. 2 ч. 1 ст. 2 Закону про публічні закупівлі, становлять органи соціального страхування, до складу яких включаються Пенсійний фонд України, Фонд соціального страхування України та Фонд загальнообов'язкового державного соціального страхування України на випадок безробіття. У разі встановлення правового статусу Пенсійного фонду України може виникнути проблема у частині його віднесення до системи центральних органів виконавчої влади або ж до самоврядної неприбуткової організації. Правові підстави для такої проблеми створює невідповідність 
норми п. 1 Положення про Пенсійний фонд України, затвердженого постановою Кабінету Міністрів України від 23.07.2014 № 280, згідно з якою Пенсійний фонд України є центральним органом виконавчої влади, діяльність якого спрямовується і координується Кабінетом Міністрів України через Міністра соціальної політики, що реалізує державну політику з питань пенсійного забезпечення та ведення обліку осіб, які підлягають загальнообов'язковому державному соціальному страхуванню, ч. 1 ст. 58 Закону України «Про загальнообов'язкове державне пенсійне страхування», відповідно до якої Пенсійний фонд $є$ самоврядною неприбутковою організацією. 3 урахуванням того факту, що Пенсійний фонд включено до переліку замовників, визначених п. 2 ч. 2 ст. 2 Закону про публічні закупівлі, можемо стверджувати, що в розумінні цього Закону такий фонд не розглядається як орган державної виконавчої влади.

Положення п. 3 ч. 2 ст. 2 Закону про публічні закупівлі дає можливість виділити сукупність юридичних ознак, за наявності яких юридична особа буде вважатися замовником у розумінні такої правової норми.

По-перше, така юридична особа має бути підприємством, установою або організацією. Правильність та необхідність закріплення такої ознаки видаються неоднозначними, адже такий поділ юридичних осіб на підприємства, установи та організації, відповідно до положень чинного законодавства, не може бути здійснений за певною однією ознакою. Так, відповідно до ч. 1 ст. 80 і ч. 3 ст. 83 Цивільного кодексу України юридичною особою є організація, створена і зареєстрована у встановленому законом порядку, а установою є організація, створена однією або кількома особами (засновниками), які не беруть участі в управлінні нею, шляхом об'єднання (виділення) їхнього майна для досягнення мети, визначеної засновниками, за рахунок цього майна. Таким чином, кожна установа $€$ юридичною особою, а отже, й організацією також. Господарський кодекс України у ч. 4 ст. 62 встановлює, що підприємство $€$ юридичною особою, має відокремлене майно, самостійний баланс, рахунки в установах банків та може мати печатки, тобто кожне підприємство є водночас й організацією. Ці терміни за своєю суттю змішуються, не є видовими поняттями стосовно родового поняття «юридична особа», а така ознака не має жодної теоретичної чи практичної цінності в аспекті визначення окремо взятої юридичної особи замовником.

По-друге, діяльність такої юридичної особи має бути спрямована на забезпечення потреб держави або територіальної громади. У площині державних потреб у правовій науці висловлюється точка зору, відповідно до якої під поняттям «державні потреби» розуміються потреби держави у повному обсязі цього слова, а не потреби органів державної влади чи суб'єктів господарювання [3, с. 17]. Це свідчить про те, що діяльність такої юридичної особи має бути спрямована на задоволення потреб держави як політичного та економічного утворення загалом чи територіальної громади як спільноти жителів окремої адміністративно-територіальної одиниці, а не створених ними органів влади чи суб'єктів господарювання. Мінекономрозвитку у своєму листі від 29.04.2016 зазначило, що потреби держави та територіальної громади характеризуються тим, що для їх забезпечення держава або органи місцевого самоврядування приймають нормативноправові акти, розпорядчі рішення, у яких фактично констатується обов'язок або функція державної інституції/місцевого самоврядування забезпечити функцію держави чи загальні потреби територіальної громади [4, с. 2-3]. Тобто, на думку Міністерства, до змісту державних потреб потрібно підходити з позицій функцій держави. У розвиток такої тези зазначимо, що в теорії держави функції держави поділяють на внутрішні (політична, економічна, соціальна, екологічна, культурна, інформаційна, правоохоронна та правозахисна) і зовнішні (співробітництва та інтеграції із сучасними державами в різних державо-правових сферах суспільного життя, функція оборони держави, забезпечення миру та підтримки світового правопорядку) [5, с. 133-135].

По-третє, законом висувається ознака, що стосується нездійснення таким замовником своєї діяльності на промисловій чи комерційній основі. Відповідно до ч. 1 ст. 42 ГК України підприємництвом є самостійна, ініціативна, систематична, на власний ризик господарська діяльність, що здійснюється суб'єктами господарювання (підприємцями) 3 метою досягнення економічних і соціальних результатів та одержання прибутку. Мінекономрозвитку у згаданому вище листі висловлює точку зору, за якою діяльність не $€$ комерційною чи промисловою, якщо держава, підконтрольні їй організації для забезпечення певної потреби держави керуються іншими мотивами, ніж прибутковість, водночас така діяльність не залежить від економічних ризиків і витрат на неї.

У разі відповідності юридичної особи, її діяльності вищенаведеним загальним ознакам для констатації у неї статусу замовника у розумінні Закону про публічні закупівлі 
вона має відповідати одному з таких додаткових критеріїв: бути або розпорядником, одержувачем бюджетних коштів, або органи державної влади, місцевого самоврядування чи інші замовники володіють більшістю голосів у вищому органі управління юридичної особи, або у статутному капіталі цієї юридичної особи державна або комунальна частка акцій (часток, паїв) перевищує 50 відсотків. Зі змісту п. 38 ч. 1 ст. 2 Бюджетного кодексу України випливає, що особа набуває статусу одержувача бюджетних коштів тільки у разі наявності бюджетної програми із затвердженим паспортом бюджетної програми та уповноваження іï розпорядником бюджетних коштів на здійснення заходів, передбачених цією бюджетною програмою. Стосовно другої додаткової ознаки потрібно усвідомлювати, що факт належності органу державної влади або місцевого самоврядування більшості голосів у вищому органі управління юридичної особи має встановлюватися з урахуванням норм чинного законодавства про порядок створення, функціонування та припинення юридичних осіб конкретної організаційно-правової форми. В аспекті третьої додаткової ознаки до уваги обов’язково мають братися положення законодавства, якими встановлюється обов'язок засновників юридичної особи сформувати статутний капітал. Так, відповідно до ч. 1 ст. 113 ЦК України господарським товариством $€$ юридична особа, статутний (складений) капітал якої поділений на частки між учасниками. Господарськими товариствами, засновники яких мають сформувати статутний капітал, є акціонерне товариство (ч. 1 ст. 152 ЦК України), товариство 3 обмеженою або додатковою відповідальністю (ч. 1 ст. 12 Закону України «Про товариства 3 обмеженою та додатковою відповідальністю»). Однак видається неможливим існування такого господарського товариства, діяльність якого не була б спрямована на отримання прибутку з метою наступного його розподілу між його учасниками, що виключає можливість належності господарського товариства до кола замовників, передбачених п. 3 ч. 2 ст. 2 Закону про публічні закупівлі, адже такі замовники мають буті наділені ознакою здійснення діяльності не на комерційній основі. Іншою організаційно-правовою формою юридичної особи, стосовно якої передбачено імперативне правило про формування статутного капіталу, є унітарне підприємство, оскільки

2 Див., зокрема: оголошення про проведення відкритих торгів з унікальними номерами: UA-2019-11-27-000514-a, UA-2019-07-29-001537-b, UA-2019-12-27-000118-c. відповідно до ч. 4 ст. 63 ГК України таке підприємство створюється одним засновником, який у тому числі формує відповідно до закону статутний капітал. Водночас державне підприємство відповідно до ст. ст. 74, 76 ГК України може бути комерційним або казенним, а комунальне підприємство згідно з ч. 3 ст. 78 цього ж Кодексу - комерційним чи некомерційним. На підставі зазначеного законодавчого поділу державних і комунальних унітарних підприємств залежно від здійснюваного виду господарської діяльності вважаємо, що державні та комунальні комерційні підприємства, незважаючи на належність державі або територіальній громаді більше 50 відсотків статутного капіталу, замовниками в розумінні п. 3 ч. 1 ст. 2 Закону про публічні закупівлі бути не можуть, адже їхня діяльність провадиться на комерційних засадах. В історичному аспекті варто зауважити, що у період дії редакції Закону про публічні закупівлі, чинній до 19.04.2020, виникали сумніви стосовно правомірності віднесення державних підприємств, основним видом економічної діяльності яких $€$ видобування кам'яного вугілля, до замовників у розумінні цього Закону, оскільки така діяльність здійснюється на комерційній та промисловій засадах (в оновленій редакції Закону про публічні закупівлі це питання вирішено шляхом доповнення переліку окремих сфер господарювання діяльністю з видобутку вугілля $)^{1}$.

Інша категорія замовників відповідно до п. 4 ч. 1 ст. 2 Закону про публічні закупівлі включає у себе юридичних осіб та/або суб'єктів господарювання, які здійснюють діяльність в окремих сферах господарювання та відповідають одній із встановлених додаткових ознак. 3 аналізу наведеного положення може скластися хибне враження, що законодавець у наведеній нормі нібито поділяє юридичних осіб та суб'єктів господарювання як дві різні категорії, зміст яких не перетинається, однак слід мати на увазі, що згідно 3 п. 1 ч. 2 ст. 55 ГК України до суб'єктів господарювання належать у тому числі юридичні особи, створені відповідно до ЦК України, державні, комунальні та інші підприємства, створені відповідно до цього Кодексу, а також інші юридичні особи. Таке положення дає підстави вважати, що поняття «юридична особа» та «суб'єкт господарювання» співвідносяться як частина та ціле, а тому недоречно виокремлювати юридичних осіб у цьому положенні. Також законом встановлено, що, окрім здійснення таким суб'єктом господарювання діяльності в окремих сферах господарювання, органам державної влади, органам влади АРК, органам 
місцевого самоврядування або іншим замовникам має належати більше ніж 50 відсотків статутного капіталу, такі суб'єкти мають володіти більшістю голосів у вищому органі управління юридичної особи та/або суб'єкта господарювання чи правом призначати більше половини складу виконавчого органу або наглядової ради такого суб'єкта. Стосовно обов'язкової наявності такої ознаки, як належність органам державної влади, органам влади АРК та органам місцевого самоврядування частки у розмірі більше ніж 50 відсотків, вважаємо за потрібне вказати таке. Зі змісту норм ч. ч. 1, 2 ст. 41, п. 3 ст. 138 Конституції України випливає, що Основний Закон України передбачає існування п'яти видів права власності: право власності Українського народу, право державної власності, право комунальної власності, право власності АРК (право публічної власності) та право приватної власності. Така ж позиція наявна й у юридичній літературі [6, с. 233]. Органи державної влади, органи влади АРК та органи місцевого самоврядування не є суб'єктами права власності, а тому у досліджуваній нормі Закону про публічні закупівлі доцільніше було б вказати про належність саме державі, територіальній громаді чи АРК більше ніж 50 відсотків статутного капіталу суб'єкта господарювання. При цьому у разі наявності у суб'єкта господарювання спеціального або ексклюзивного права, набутого ним не за результатами проведення конкурсної процедури (наприклад, надання спеціального дозволу на користування надрами без проведення аукціону відповідно до п. 8 Порядку надання спеціальних дозволів на користування надрами, затвердженого Постановою Кабінету Міністрів України від 30.05.2011 № 615), питання приналежності частки у статутному капіталі державі, територіальній громаді, АРК чи іншим замовникам не матиме значення.

\section{Висновки}

Проаналізувавши норми оновленого Закону про публічні закупівлі в частині його норм, що закріплюють юридично значимі ознаки замовників, можемо стверджувати, що мету цієї статті досягнуто. По-перше, під час встановлення юридично значущих ознак замовників виявлено, що законодавство містить певні недоліки, адже не враховує, що деякі державні органи за чинним законодавством України не є ані органами державної влади, ані правоохоронними органами держави. По-друге, обгрунтовано недоцільність використання такої ознаки для юридичної особи, як наявність у неї статусу підприємства, установи, організації. По-третє, продемонстровано, що виникають проблеми під час тлумачення змісту такої ознаки, як здійснення господарської діяльності не на промисловій та комерційній основах. По-четверте, проілюстровано, що в Законі про публічні закупівлі у новій редакції безпідставно розмежовано юридичних осіб та суб'єктів господарювання, а також хибно закріплена ознака належності органам державної влади чи органам місцевого самоврядування часток у статутному капіталі.

Переконані, що наукова розвідка щодо цього питання має продовжуватися, адже практика застосування нового Закону про публічні закупівлі та майбутній досвід вирішення спорів виявлятимуть недосконалості чинного нормативно-правового регулювання, що зумовлюватиме потребу у внесенні відповідних змін.

\section{Список використаних джерел:}

1. Шатковський О. Гармонізація системи державних закупівель в Україні за стандартами ЄC: коментарі до законодавства України про публічні закупівлі / О. Шатковський, С. Яременко. 2016. $131 \mathrm{c}$.

2. Рішення Конституційного Суду України у справі за конституційним поданням 46 народних депутатів України щодо відповідності Конституції України (конституційності) окремих положень Закону України «Про Національну комісію, що здійснює державне регулювання у сферах енергетики та комунальних послуг» (справа про Національну комісію, що здійснює державне регулювання у сферах енергетики та комунальних послуг): Рішення Конституційного Суду України від 13.06.2019 № 5-p/2019. URL: https:// zakon.rada.gov.ua/laws/show/v005p710-19.

3. Єжель О. Л. Тлумачення поняття державних потреб у сфері державного замовлення Науковий вісник Міжнародного гуманітарного університету. Серія «Юриспрудениіл». 2013. Випуск № 6-1, т. 2. Маріуполь, 2014. С. 242-247.

4. Щодо здійснення закупівель замовниками: Лист Міністерства економічного розвитку і торгівлі України. URL: http://me.gov.ua/Documents/ List?lang=uk-UA\&tag=ListiInformativnogoKharak teru.

5. Скакун О.Ф. Теорія держави і права : підручник. 2-ге вид., доповнене і перероблене. Київ : Правова єдність, 2010. 520 с.

6. Харитонов Є. О., Старцев О. В. Цивільне право України : підручник. Вид. 2, перероб. і доп. Київ : Істина, 2007. 816 с 
The article deals with the illustration of national public procurement legislation novelties regarding the definition of the range of customers that are required to procure through the application of the procedures established by law. It is determined that the updated law on public procurement modernized the list of customers, which causes the interest of scholars and practitioners in identifying the deficiencies of regulations.

The article substantiates that the legislator unjustifiably bypassed a number of state bodies, which under the current legislation are not part of any of the branches of government, are not law enforcement, but at the same time exercise their authority to perform the regulatory functions of the state in certain spheres of economic activities. It is also noted that the law contains an outdated division of legal entities into enterprises, institutions, organizations, which by its very nature does not carry any theoretical or practical value when deciding whether a separate legal entity is a costumer. Emphasis is placed on the problem of defining the characteristics of economic activity on an industrial or commercial basis, as evidenced by the procurement procedures of state-owned commercial enterprises whose economic activity is commercially oriented, i.e. profit-oriented according to the provisions of the current legislation. At the same time, the law without sufficient grounds divides the term "legal entities" and "economic entities" as terms whose content does not seem to intersect. In addition, the article concludes that it is inadmissible to state in the law a feature of belonging shares in the authorized capital of a legal entity to state bodies or local self-government bodies. In addition, the law indicates that there is one case where the identity of a legal entity engaged in activities in certain areas of business is established regardless of the existence of a link between such a legal entity and public authorities, local self-government bodies and authorities of the ARC.

Key words: customers, public procurement, certain areas of business, public authorities, local self-government bodies, commercial activity. 